\title{
ALIRAN ANTROPOLOGI HUKUM
}

\author{
Nama : MERLIA RAHMA \\ BP : 2010003600109 \\ Email: adekmelia1789@gmail.com \\ Fakultas Hukum Universitas Eka Sakti
}

2021

\section{KATA PENGANTAR}

Puji syukur penulis panjatkan kehadirat Tuhan Yang Maha Kuasa karena atas izinNyalah

penulis masih diberikan kesempatan untuk menyusun makalah Antropologi Hukum tentang ALIRAN ANTROPOLOGI HUKUM, tugas dan pedoman. Dalam penyusunan makalah ini penulis mengumpulkan dari berbagai sumber terutama dari internet yang memudahkan saya dalam menyelesaikan tugas ini. Penulis menyadari bahwa makalah ini

sangat jauh dari kesempurnaan walaupun kita menginginkan kesempurnaan Dalam hal pembangunan dan penyempurnaan makalah ini penulis mengharapkan kritik, masukan dan saran yang bersifat membangun dari pembaca. 


\section{A. PENDAHULUAN}

Dalam Modul ini akan diuraikan tentang Aliran Antropologi Hukum. Secara umum Ilmu Pengetahuan berasal dari filsafat. Ilmu-ilmu sosial seperti sosiologi dan antropologi lahir setelah perkembangan ilmu-ilmu alam. Ilmu sosiologi muncul setelah industrialisasi berlangsung di Eropa. Pesatnya pertumbuhan industri menyebabkan berkembangnya kota-kota industri di Eropa. Industrialisasi sebabkan perubahan sosial masyarakat Eropa, menyebabkan perubahan nilai-nilai di dalam masyarakat. Ini mendorong ilmuan mempelajari keadaan masyarakat Eropa yang sedang berubah tersebut, lahirlah ilmu Sosiologi.

Antropologi lahir setelah orang Eropa mendatangi negeri-negeri di benua Asia, Afrika dan Oceania yang dimulai sebelum tahun 1800, yang didorong oleh keinginan untuk memperoleh bahan-bahan dasar pengembangan industri serta untuk mencari daerah pemasaran hasil industri yang mulai maju di Eropa. Dalam perjalanan tersebut orang Eropa menemukan bangsa-bangsa (suku bangsa-suku bangsa) yang belum berkembang, dianggap primitif atau terbelakang. Penemuan suku bangsasuku bangsa ini kemudian mendorong keinginan ilmuan mempelajari kebudayaan yang berbeda - beda yang tersebar di permukaan bumi. Maka timbullah kajian etnologi (ilmu tentang bangsa-bangsa).

Antropologi semakin berkembang karena adanya aliran -aliran yang bermunculan dan berkembang. Aliran antropologi tersebut adalah sebagai

berikut:

-Aliran evolusionalosme

-Aliran kognitif

-Aliran struktural

-Aliran antropologi simbiolik

-Aliran fungsionalisme

\section{B.PEMBAHASAN}

Kajian yang lebih serius terhadap suku-suku bangsa atau banga di dunia mulai dilakukan ilmuan pada pertengahan abad ke-19, yang turut dipengaruhi oleh cara berfikir evolusionis dari Charles Darwin. Oleh karena itu teori-teori awal yang dihasilkan antropologi juga mengklasifikasikan dan membanding-bandingkan bangsa dan suku bangsa-suku bangsa di dunia dan menempatkan bangsa atau suku bangsa itu ke dalam tingkatan tertentu sesuai dengan perkembangan kebudayaan dan ciri-ciri kebudayaan material yang mereka miliki. 
Awal abad ke dua puluh oleh Bronislaw Malinowski penelitian antropologi semakin maju dengan pendekatan wholistic dan paradigma atau teori fungsionalisme yang dikembangkannya dari penelitiannya di Trobriand, dengan hasil karya etnografi berjudul The Arganouts From Western Pacific. Sejak itu antropologi mengalami kemajuan yang pesat. Paradigma atau teori baru dihasilkan dalam rangka mengeksplanasikan atau mendeskripsikan kebudayaan masyarakat di dunia. Kajian etnologi yang hanya mengandalkan data-data sekunder mulai ditinggalkan dan menggantinya dengan penelitian lapangan (fieldwork) etnografi.

Beberapa teori yang telah dihasilkan para ahli dalam menjelaskan perbedaan kebudayaan dengan kerangka why societies differ, di antaranya:

a. Rasialisme, yang melihat tingkat kebudayaan terjadi karena perbedaan ras.

b. Universal Evolution, yang membuat perbedaan tegas antara sifat-sifat yang diwarisi secara biologis dan sifat yang diperoleh secara sosial.

c. Evolusi pemikiran manusia. E.B. Tylor sebagai contoh yang membedakan antara manusia primitif dari manusia modern adalah bahwa yang satu masih percaya kepada tahyul, sedangkan yang lain berfikir rasional menurut prinsip keilmuan.

d. Evolusi teknologi. L. H. Morgan sebagai contoh yang mengatakan inovasi teknologi adalah faktor pokok yang akan mempengaruhi aspek- aspek lain dalam kehidupan manusia, dalam perbedaan tingkat kebudayaan manusia.

Adapun aliran-aliran antropologi hukum antara lain :

\section{Aliran Evolusionalisme}

Asumsi dasar yang mengalami proses perubahan dari suatu tahap selanjutnya secara evolutif.

-> Tokoh-tokoh yang terkenal pada aliran evolusionalisme :

a.) E.B Tylor dengan teori animisme

b.) J.J Bosfon dengan teori pembentukan keluarga

c.) J.G Frazer dengan teori batas akal

d.) R.R Maref dengan teori dewa tertinggi

-> Kebudayaan dalam perspektif Evolusionalisme terbagi dalam 3 konsep :

a.) Kebudayaan sebagai sebuah sistem yaitu adanya gagasan fikiran, konsep, nilai, norma dll yang sifatnya abstrak

b.) Kebudayaan sebagai sosial sistem dengan ada unsur kebudayaan

c.) Kebudayaan material fultur dengan budaya material

->Ciri-ciri Evolusionalisme

a.) Mempunyai perspektif yang sama mengenai perubahan secara perlahan

b.) Tujuannya bersifat komparatif

c.) Tinjauannya bersifat universal

2. Aliran Kognitif

->Aliran Koginif adalah dasar memandang kebudayaan sebagai kognisi manusia atau 
melihat antara bahasa, kebudayaan, dan kognisi manusia

-> Tokoh-tokoh yang terkenal pada aliran kognitif :

W.H Guci The Nob , memandang kebuayaan bukan sebagai fenomena material atau benda, perilaku, emosi, menjadi bagian cara pandangan pengaturan hal hal tsb. menjelaskan bagaimana manusia memandang benda atau kejadian dan makna dari dunia sendiri. Cara pandang dilihat dari bahasa dengan budaya dan kepribadian dengan budaya akan menjadi analisis kosa kata ada dikarakter manusia berjuang pada perubahan kebudayaan.

\section{Aliran Struktural}

-> Asumsi dasar adalah nalar manusia merupakan sistem relasi tokoh-tokoh :

Levis Straus menjelaskan bahwa kebudayaan dan bahasa berpartisipasi sejajar keduanya yang merupakan hasil nalar manusia.

\section{Aliran Antropologi Simbiolik}

-> Asumsi dasar menyatakan kebudayaan adalah keseluruhan pengetahuan manusia yang dijadikan sebagai pedoman keseluruhan tindakan manusia. Kebudayaan adalah pedoman bagi masyarakat yang diyakini kebenarannya bagi masyarakat tsb.

\section{Aliran Fungsionalisme}

->Muncul sebagai reaksi terhadap pemikiran kaum evolusionis dimana dasar pemikiran dianalisa sebagai bagian-bagian yang terpisah satu dengan lainnya dan saling ketergantungan berdasarkan fungsi. Contoh ; hukum dalam masyarakat. Teori tidak lagi bersifat universal tetapi mengenai masyarakat atau suku bangsa atau desa tunggal.

Pemahaman fungsionalistis tentang masyarakat dan kebudayaan harus dituangkan dalam bentuk eknografi. Fungsi dari setiap kegiatan selalu berulang seperti penghukuman kejahatan atau upacara pengeburan merupakan bagian yang dimainkan dalam kehidupan sosial sebagai pengukuhan. Karena itu merupakan sumbangan yang diberikan bagi pemelihara kelangsungan struktural. Menurut "Bronislaw Malinosky" secara garis besar bentuk rangka teori untuk menganalisa fungsi dari kebudayaan manusia yang disebut subs teori fungsional tentang kebudayaan.

\section{PENUTUP}

Antropologi lahir karena adanya perhatian kalangan ilmuan di Eropa kepada masyarakat yang masih dianggap primitif atau masyarakat sederhana di Asia, Afrika dan Oceania yang didorong oleh banyaknya tulisan dari petualang, penyebar agama atau para industrialis yang melakukan perjalanan untuk mencari pengembangan industri dan daerah pemasarannya. 
Dari kerangka berfikir how societies differ telah menjelaskan mengapa masyarakat berbeda, di antaranya:

(1) Teori Fungsionalisme. Malinowski sebagai contoh, mengatakan

kebudayaan dan institusi sosial berkembang dalam rangka usaha manusia memenuhi kebutuhan hidup manusia, yang diupayakan secara kultural.

(2) Teori Struktural-Fungsionalisme dari Radcliffe-Brown, yang mengatakan bagaimana elemen-elemen dari struktur sosial menciptakan dan menjaga keseimbangan tatanan sosial dalam keadaan equilibrium.

(3) Teori Strukturalisme (Perancis) dari Claude Levi-Strauss mengatakan bahwa cara manusia bertingkah laku dan memandang dunia ditentukan oleh mind-nya.

(4) Teori Etnoscience. Harold Conclin : berusaha menemukan prinsip struktural dari budaya tertentu-bagaimana masyarakat memandang dunia mereka dan bagaimana anggota-anggota dari masyarakat menerima serta memahami dan menstrukturkan lingkungan mereka melalui kategori-kategori bahasa.

(5) Antropologi Simbolik. Clifford Geertz mengatakan bahwa cultur is a system of shared symbols and meanings (kebudayaan adalah sistem simbol dan makna yang dimiliki bersama)

\section{D.DAFTAR PUSTAKA}

Darmini Roza dan Laurensius Arliman S Peran Pemerintah Daerah Di Dalam Melindungi Hak Anak Di Indonesia, Masalah-Masalah Hukum, Volume 47, Nomor 1, 2018.

Laurensius Arliman S, Komnas HAM dan Perlindungan Anak Pelaku Tindak Pidana, Deepublish, Yogyakarta, 2015.

Laurensius Arliman S, Penguatan Perlindungan Anak Dari Tindakan Human Trafficking Di Daerah Perbatasan Indonesia, Jurnal Selat, Volume 4, Nomor 1, 2016.

Laurensius Arliman S, Problematika Dan Solusi Pemenuhan Perlindungan Hak Anak Sebagai Tersangka Tindak Pidana Di Satlantas Polresta Pariaman, Justicia Islamica, Volume 13, Nomor 2, 2016.

Laurensius Arliman S, Pelaksanaan Perlindungan Anak Yang Tereksploitasi Secara Ekonomi Oleh Pemerintah Kota Padang, Veritas et Justitia, Volume 2, Nomor 1, 2016. Laurensius Arliman S, Kedudukan Ketetapan MPR Dalam Hierarki Peraturan Perundang-Undangan Di Indonesia, Lex Jurnalica, Volume 13, Nomor 3, 2016.

Laurensius Arliman S, Komnas Perempuan Sebagai State Auxialiary Bodies Dalam Penegakan Ham Perempuan Indonesia, Justicia Islamica, Volume 14, Nomor 2, 2017. Laurensius Arliman S, Peranan Pers Untuk Mewujudkan Perlindungan Anak Berkelanjutan Di Indonesia, Jurnal Ilmu Hukum Tambun Bungai, Volume 2, Nomor 2, 2017.

Laurensius Arliman S, Mewujudkan Penegakan Hukum Yang Baik Untuk Mewujudkan Indonesia Sebagai Negara Hukum, Jurnal Hukum Doctrinal, Volume 2, Nomor 2, 2017. Laurensius Arliman S, Participation Non-Governmental Organization In Protecting Child Rights In The Area Of Social Conflict, The 1st Ushuluddin and Islamic Thought International Conference (Usicon), Volume 1, 
2017.

Laurensius Arliman S, Partisipasi Masyarakat Dalam Pembentukan PerundangUndangan Untuk Mewujudkan Negara Kesejahteraan Indonesia, Jurnal Politik Pemerintahan Dharma Praja, Volume 10, Nomor 1, 2017, https://doi.org/10.33701/jppdp.v10i1.379.

Laurensius Arliman S, Peran Komisi Perlindungan Anak Indonesia Untuk Mewujudkan Perlindungan Anak, Jurnal Respublica Volume 17, Nomor 2, 2018. Laurensius Arliman S, Menjerat Pelaku Penyuruh Pengrusakan Barang Milik Orang Lain Dengan Mempertimbangkan Asas Fungsi Sosial, Jurnal Gagasan Hukum, Volume 1, Nomor 1, 2019. Laurensius Arliman S, Ilmu Perundang-Undangan Yang Baik Untuk Negara Indonesia, Deepublish, Yogyakarta, 2019. Laurensius Arliman S, Isdal Veri, Gustiwarni, Elfitrayenti, Ade Sakurawati, Yasri, Pengaruh Karakteristik Individu, Perlindungan Hak Perempuan Terhadap Kualitas Pelayanan Komnas Perempuan Dengan Kompetensi Sumber Daya Manusia Sebagai Variabel Mediasi, Jurnal Menara Ekonomi: Penelitian dan Kajian Ilmiah Bidang Ekonomi, Volume 6, Nomor 2, 2020. Laurensius Arliman S, Pendidikan Kewarganegaraan, Deepublish, Yogyakarta, 2020. Laurensius Arliman S, Makna Keuangan Negara Dalam Pasal Pasal 23 E Undang-Undang Dasar 1945, Jurnal Lex Librum, Volume 6, Nomor 2 Juni 2020, http://dx.doi.org/10.46839/1ljih.v6i2.151.

Laurensius Arliman S, Kedudukan Lembaga Negara Independen Di Indonesia Untuk Mencapai Tujuan Negara Hukum, Kertha Semaya Journal Ilmu Hukum, Volume 8, Nomor 7, 2020.

Laurensius Arliman S, Pelaksanaan Assesment Oleh Polres Kepulauan Mentawai Sebagai Bentuk Pelaksanaan Rehabilitasi Bagi Pecandu Dan Korban Penyalahgunaan Narkotika, Jurnal Muhakkamah, Volume 5, Nomor 1, 2020.

Laurensius Arliman S, Aswandi Aswandi, Firgi Nurdiansyah, Laxmy Defilah, Nova Sari Yudistia, Ni Putu Eka, Viona Putri, Zakia Zakia, Ernita Arief, Prinsip, Mekanisme Dan Bentuk Pelayanan Informasi Kepada Publik Oleh Direktorat Jenderal Pajak, Volume 17, No Nomor, 2020.

Larensius Arliman S, Koordinasi PT. Pegadaian (Persero) Dengan Direktorat Reserse Narkoba Polda Sumbar Dalam Penimbangan Barang Bukti Penyalahgunaan Narkotika, UIR Law Review, Volume 4, Nomor 2, 2020, https://doi.org/10.25299/uirlrev.2020.vol4(1).3779. Laurensius Arliman S, Tantangan Pendidikan Kewarganegaraan Pada Revolusi 4.0, Ensiklopedia Sosial Review, Volume 2, Nomor 3, 2020.

Muhammad Afif dan Laurensius Arliman S, Protection Of Children's Rights Of The Islamic And Constitutional Law Perspective Of The Republic Of Indonesia, Proceeding: Internasional Conference On Humanity, Law And Sharia (Ichlash), Volume 1, Nomor 2, 2020.

Otong Rosadi danLaurensius Arliman S, Urgensi Pengaturan Badan Pembinaan Idelogi Pancasila Berdasarkan Undang-Undang Sebagai State Auxiliary Bodies yang Merawat Pancasila dalam Perspektif Hak Asasi Manusia, Prosiding Konferensi Nasional Hak Asasi Manusia, Kebudayaan dan Tujuan Pembangunan Berkelanjutan Indonesia pada Masa Pandemi Covid-19: Tantangan untuk Keilmuan Hukum dan Sosial Volume 1, Universitas Pancasila, Jakarta, 2020. 